\title{
Formation of intercultural competence among schoolchildren in Great Britain
}

\section{ФОРМИРОВАНИЕ ИНТЕРКУЛЬТУРНОЙ КОМПЕТЕНЦИИ У ШКОЛЬНИКОВ НА ПРИМЕРЕ ОПЫТА ВЕЛИКОБРИТАНИИ}

Received: January 6, 2021

Accepted: February 28, 2021

\author{
Written by: \\ Larisa M. Zakharova ${ }^{\text {s0 }}$ \\ https://orcid.org/0000-0001-6363-2900 \\ Tatiana A. Chibisova ${ }^{51}$ \\ https://orcid.org/0000-0001-5495-0376
}

\begin{abstract}
The study identifies the term intercultural competence and distinguishes its main components. The authors examine the experience of Great Britain in the formation of this competence among schoolchildren in the historical perspective from the beginning of the twentieth century to the present. The study of the main methods used in multicultural classes in Great Britain and in many countries of Europe made it possible to group them according to the components of intercultural competence.

In order to identify the level of development of this competence among future teachers themselves, there were interviewed the students of Ulyanovsk State Pedagogical University named after I.N. Ulyanov. The diagnostic assessment was also conducted for British students who showed a significantly higher level of tolerance compared to Russian students.

Therefore, it was thought appropriate to refer to the experience of teacher training in Great Britain that has developed a certain system of training future teachers who are ready to work in a multicultural environment. The comparative analysis of the curricula of 15 leading universities in Great Britain revealed a number of features in teacher training, including the development of their readiness to work in a multicultural educational environment.

The experience of Great Britain in the formation of intercultural competence among schoolchildren and future teachers made it possible to determine the directions and trends of their development in modern Russian education at two levels: at the level of school education and at the level of higher education related to the
\end{abstract}

\begin{abstract}
Аннотация
В исследовании дается определение термина «интеркультурная компетенция» и выделяются его основные компоненты. Авторы исследуют опыт Великобритании в части формировании данной компетенции у школьников в исторической ретроспективе с начала XX века по настоящее время. Изучение основных методов, используемых в мультикультурных классах Великобритании и во многих странах Европы, позволило сгруппировать их по выделенным компонентам интеркультурной компетенции.

С целью выявления уровня развития данной компетенции у самих будущих педагогов были опрошены студенты Ульяновского Государственного Педагогического Университета имени И. Н. Ульянова. Диагностика также проводилась среди британских студентов, которые показали значительно более высокий уровень толерантности по сравнению с российскими студентами.

Поэтому было сочтено уместным сослаться на опыт подготовки учителей в Великобритании, разработавшей определенную систему подготовки будущих педагогов, готовых работать в мультикультурной среде. Сравнительный анализ учебных планов 15 ведущих университетов Великобритании выявил ряд особенностей в подготовке учителей, в том числе развитие их готовности работать в мультикультурной образовательной среде. Опыт Великобритании в формировании интеркультурной компетенции у школьников и будущих учителей позволил
\end{abstract}

\footnotetext{
${ }^{50}$ Doctor of Pedagogical Sciences, Professor Ulyanovsk State Pedagogical University named after I.N.Ulyanov, Russia.

${ }^{51}$ Senior Teacher Ulyanovsk State Pedagogical University named after I.N.Ulyanov, Russia.
} 
preparation of teachers for work in multicultural classes.

Key Words: diversity, ethnic identity, intercultural competence, multicultural communication, tolerance. определить направления и тенденции их развития в современном российском образовании на двух уровнях: на уровне школьного образования и на уровне высшего образования.

Ключевые слова: разнообразие, этническая идентичность, интеркультурная компетенция, коммуникация, толерантность.

\section{Introduction}

The current situation in the world, and the increasing conflicts taking place on racial, religious and cultural grounds, lead to the need to review the policies of multinational states not only with regard to national minorities and their interaction with indigenous ethnic groups, but also to pay attention to the full range of problems of intercultural communication that arise in the multicultural environment of the state.

We turned to the experience of Great Britain as a country on the territory of which historically coexist both representatives of indigenous ethnic groups - the British, the Scots, the Welsh, the Irish, and migrants from the countries of the former colonies, possessing a radically different culture, customs, religions. As a result, educational institutions faced a changed composition of students, which led to the need to revise the basic models of education and upbringing in line with the new reality.

This study examines the experience of Great Britain in the formation of intercultural competence among schoolchildren in the historical perspective from the beginning of the twentieth century to the present. This historical period was not chosen by chance - it was at the beginning of the 20th century after the collapse of the colonies of the British Empire that the country was flooded with migrants, as a result of which the country's education system had to respond to the changed social and cultural composition of the population.

The purpose of this study is to determine the features of the formation of intercultural competence of school-age children based on the experience of Great Britain and to identify the trends in solving this problem in education in this country that could be implemented in modern Russian education. As a multinational state, Russia, like most Western countries, has faced problems of changing the national and cultural composition of students due to active internal and external migration.

\section{Theoretical framework}

First of all, we should refer to the content of the concept of "intercultural competence."

Deardorff (2006) sees intercultural competence as the ability to develop the necessary knowledge, skills and relationships that lead to proper behavior and communication necessary for intercultural relations.

Sinicrope et al, (2007) emphasizes that intercultural competence implies the ability of students to cooperate with representatives of other cultures in the process of communication.

Many researchers abroad distinguish communicative competence within the framework of intercultural competence (Spitzberg, 2000). Communicative competence is seen by them as the use in speech, as well as an understanding of certain words and other communicative forms that make sense for both the speaker and the rest of the participants of communication. It is noted that the ability to form sentences from words is just the beginning of communication. Speakers should be familiar with social and cultural contexts (where, when, under what circumstances communication takes place). Here we see an intersection with the contextual theory of communication of the American anthropologist E. Hall, who in his book "The Silent Language" argued that the condition for successful intercultural communication is that communicants know the context of communication (time, space, social conditions) (Hall, 1968).

Byram (1997) states that intercultural communicative competence includes models of relationships in which students mutually learn a 
different language, culture, moral and value attitudes.

In Russian pedagogical scientific literature, the term intercultural competence is translated as multicultural/intercultural competence, while no differences were found in the interpretation of these concepts.

Safonova (1996) considers intercultural competence as a structural component of the communicative competence of an individual.

Sadokhin (2009) defines intercultural competence as a set of knowledge and skills that contribute to effective communication.

Galskova, Gez (2007) see intercultural competence as an ability that allows an individual to be realized within the framework of intercultural communication.

Potorochina (2001) in the research uses the term intercultural competence and considers it as the ability and readiness for dialogue of cultures on the basis of the system of abilities, skills, knowledge of a modern sociocultural system of the country of the learned language, the ability to carry out the analysis of the native and studied culture.

We, in turn, adhere to the term intercultural competence, since we consider the concepts of "intercultural communication" and "multicultural communication" to be narrowly significant, with which the concept of intercultural competence is interconnected. It is important to note that among Russian scientists dealing with the problems of intercultural communication, there is still no consensus in the translation of this term into Russian. Accordingly, Zeleeva (2015), Semenova (2012) believe that multicultural communication involves tolerance to other cultures, a different worldview, other traditions, while intercultural communication involves the joint development of common values, the search for meanings, the formation of common, intersubjective values. In support of their theory, they distinguish such a phenomenon as interculture, which is seen as a phenomenon of interaction between representatives of different cultures, while possessing a supra-personal or supra-subjective, stochastic and unpredictable character. Suprapersonal meanings arise as a result of joint efforts, generating an intersubjective reality. Therefore, it is the concept of intercultural communication that reflects this intersubjective reality.
The expediency of applying the term intercultural is also explained from a linguistic point of view: the prefix inter- in English has several meanings (Apresyan, 1997): among, over- (intersect-cross); (interaction, relationship; interchange-exchange), which reflects the full interaction between people of different cultures. The term "multicultural" does not take into account the mutual influence of communicants.

In our opinion, intercultural competence is one of the key competencies, the possession of which is facilitated by effective intercultural communication, and a prerequisite for its formation is the development of communicative competence, since effective interaction between representatives of different cultures is impossible without the knowledge of proper oral and written speech skills, and proficiency in a foreign language of one of the parties contributes to faster and more effective intercultural communication.

Regarding the structure of intercultural competence, the analysis of domestic and foreign studies on the problem of intercultural competence allowed us to distinguish its main components, which are presented in these theories:

1) cognitive (Byram's theory: knowledge of native and other cultures, norms and rules, ethics of behavior) (Byram, 1997).

2) functional (the central component of Bennett's theories (Bennet, 2004, Gudykunst, 1998): the skills of applying this knowledge when communicating with representatives of a different culture, corresponding behavior in a certain situation or context

3) personal (a key component according to Deardorff: an internal mood for effective intercultural communication, confidence in one's own knowledge, skills to establish intercultural contacts) (Deardorff, 2006)

Barrett M., Academic Director of the Center for Research on Nationalism, Ethnicity and Multiculturalism, identifies 4 components of intercultural competence:

1) the attitude - respect, interest in other culture, openness, tolerance.

2) skills - to listen and hear other people, to communicate with representatives of other cultures, to adapt in a different cultural environment, linguistic skills, empathy, the ability to find information about other cultures, cognitive flexibility. 
3) knowledge about your own culture, about other cultures, linguistic knowledge

4) behavior - correct behavior during intercultural contacts, flexibility (Barrett, 2012).

In his classification, he divided the functional component into skills and characteristics of behavior. We believe that the latter are the parts of one component - the functional one, since they characterize the ability to apply knowledge (cognitive component) along with personal attitudes (affective component) in the process of intercultural interaction.

If we draw attention to the definitions of intercultural or global competence made by other foreign scientists, such as Brustein, W. I. (2006), Deardorff, D.K. (2006), we will also see the following main components of intercultural competence: knowledge, skills, attitude.

So, having analyzed the existing views of both Russian and foreign scientists on the structure of intercultural competence, we state that intercultural competence includes functional, cognitive, affective components. We define intercultural competence as a system of knowledge about one's own and other cultures, the contextual characteristics of a particular culture, as well as the skills of effective intercultural communication to be applied in practice, effective interaction with representatives of other cultures, communicative skills, together with a set of specific personal qualities of a successful communicator: communicability, cultural empathy, reflexivity, adaptability.

The formation of intercultural competence of schoolchildren, according to the European organization UNESCO (UNESCO, 2013), should be carried out in accordance with three main principles:

1. respect for the individual's own cultural identity

2. transferring to the student a certain system of knowledge, behaviors, moral principles necessary for a full life in modern society.

3. the above knowledge should enable them to respect, understand the ethnic, social, cultural and religious differences in society.

Based on this, Bednarz \& Leoni (2010) identified 6 basic methodological principles that should be taken into account in the process of formation of intercultural competence:
1. to focus on a conscious, thoughtful, analytical study of the foundations of one's own and someone else's cultures, the peculiarities of life, traditions, standards of morality, etc. The knowledge of the basic cultural principles of another culture In combination with the norms of their own culture is proved by later investigations in this field (Aziz, et al, 2020).

2. to consider the formation of intercultural competence as a continuous process

3. to review the organization of the educational space in order to take into account the rights and freedoms of national, cultural, religious and other minorities

4. to adopt a strategic approach in intercultural education, which is expressed in the development and subsequent gradual targeted implementation of a strategy for the development of intercultural education at both the state and intra-school levels

5. to combine the learning process with the solution of real life situations,

6. to take into account the accepted norms of behavior in a multicultural society.

Having studied the main methods used in multicultural classes in the UK and in many countries of Europe (Navaiyience, Rimkeviviene, 2013), we grouped them according to the components of intercultural competence identified above:

1) Methods aimed at developing a cognitive component (a certain set of knowledge about one's own and other cultures, as well as contextual features of communication):

- Design work

- Ethnographic tasks

- Survey of the área

- Presentations of one's own culture

- Development of conceptual plan

- Working in a virtual lab

- Watching videos

- Analysis of media materials

2) Methods aimed at developing the functional component (skills to carry out intercultural communication, use the acquired knowledge, establish contact with representatives of other ethnic groups, cultures):

- Online communication, working in a virtual lab

- Discussion

- Story 
- Media analysis

- Intercultural shock

- Working in a virtual lab

- Role-playing game

- Stop frame

- Case method

3) Methods aimed at developing an affective component (a certain set of personal qualities that contribute to effective intercultural communication):

- Maintaining introspection diaries

- Analysis

- Discussion

- On-line laboratory, direct communication.

In our opinion, the first priority is the formation of a cognitive component of intercultural competence. The student must acquire or deepen the knowledge already available about their own culture, as well as know about the diversity and characteristics of other cultures. Of all the above methods, research projects contribute most effectively to the development of this component. By carrying out tasks aimed at studying a particular aspect of culture, traditions, the student develops strong knowledge about the diversity of cultures, religions, and ethnic groups in the world. This work is more theoretical in nature, while the following method - performing ethnographic tasks, studying the terrain, customs, foundations, rites - can help students test their knowledge in practice, and present the knowledge to classmates and other students in the format of a presentation or conceptual plan. For a full study in a particular field, the student can be helped by the virtual laboratory method, since with the help of modern computer and information technologies, the child can contact representatives of other cultures and nationalities anywhere in the world, thereby receiving the most up-to-date information. Bakholskaya, et al. (2019) also consider the necessity of using interactive methods in formation of intercultural competence and tolerance.

In the process of working in a virtual laboratory, the student also improves the skills of intercultural communication. Thus, a functional component of intercultural competence is formed. The use of the method of cultural shock, although being costly, in a very short time contributes to the formation of a skill of interaction with representatives of other ethnic groups and cultures. The student learns to establish interpersonal contacts, adapt in various cultural contexts, take into account the contextual features of communication. This is also facilitated by methods such as the method of discussion, the method of storytelling, the method of analyzing media materials. In the process of discussing a particular phenomenon, incident, event, the formation of communicative skills also takes place (correct construction of a conversation, knowledge of the basics of a foreign language, the rules of verbal and nonverbal communication).

It is extremely important to live in certain critical situations, play them, which can be carried out using role-playing methods, the case method. In the process of the game, it is possible to analyze a hypothetical critical situation, work out the ways to get out of it, outline the main techniques, which is also extremely important in the process of forming intercultural competence.

In the process of the above-described direct communication with representatives of a different culture, in person or online, as well as in the process of playing certain controversial situations, the student forms a personal attitude to certain cultural phenomena. In the process of discussing events, incidents related to cultural or ethnic differences between people, an affective component of intercultural competence is formed, that is, the child has a certain set of qualities of an effective communicator, and his own attitude to representatives of other ethnic groups and cultures is also developed. Keeping a diary of introspection will allow the student to see themselves from the outside, mark problems, if necessary, seek help from a tutor, mentor to find optimal solutions.

It should be noted that this classification of methods by components of intercultural competence is quite relative. We believe that it is advisable to use all the above methods in complex, since the use of many of them affects the formation of all components. For example, in the process of working in a virtual online laboratory, a student communicates with representatives of different ethnic groups, while gaining knowledge of another culture, developing the skill of intercultural communication and forming their attitude to a particular phenomenon in another culture. The method of discussion, analysis is to be applied after watching videos about other cultures, while the discussion contributes to the development of a set of certain personal qualities, cognitive abilities, as well as the unique vision of many phenomena.

The analysis of the methods used in multicultural classes in the UK, as well as in many countries of 
Europe, suggests that it is necessary to develop systematically all the three components of intercultural competence. They are inextricably connected with each other, have a mutual influence on each other. It is important to give students not only knowledge of the existence of cultural diversity in the world, but also to form a certain set of qualities of an effective communicator, giving them the opportunity to practice intercultural communication either when meeting in person with representatives of different cultures, or when communicating online. The role of the teacher in this process is organizational. A very important point in the experience of Great Britain we see in the practice of mentoring, tutoring. Students need to be guided, their behavior adjusted. They should be given an opportunity to seek help at any time from either a tutor teacher or a mentor from more experienced school students. This practice avoids the so-called bullying, that is, humiliation of human dignity. This contributes to the cohesion of the school team around one extremely important goal - successful education in a multicultural community.

\section{Methodology}

In the process of formation of intercultural competence, one of the key conditions is the presence of this competence among teachers themselves. In our study, we analyzed the system of training teachers in 15 leading universities in the UK, conducted a diagnostic cut to identify the formation of intercultural competence, comparing the results with the diagnosis of Russian students.

In order to identify the level of development of intercultural competence, future teachers were interviewed, among them were the students of linguistic and non-linguistic specialties of Ulyanovsk State Pedagogical University named after I.N. Ulyanov with the help of "Methodology for diagnosing general communicative tolerance proposed by V.V. Boiko" (Grishina, Zelenov, Lunin, 2016). This technique makes it possible to diagnose tolerant and intolerant personality settings manifested in the communication process. The survey was also conducted according to the methodology "Types of ethnic identity" by G.U. Soldatova, S.V. Ryzhova (Grishina, Zelenov, Lunin, 2016) which allows diagnosing the degree of ethnic tolerance among respondents based on an analysis of attitudes towards representatives of their own and other ethnic groups.
The sample was 59 people, of which 39 people were students of the Faculty of Foreign Languages and 20 were students of nonlinguistic specialties of the university. These categories of respondents were chosen due to the fact that students of linguistic specialties are more focused on learning the language, cultural specifics, and develop readiness to interact with representatives of other cultures.

\section{Results and discussion}

Analysis of diagnostic results (for a more detailed description of the course of diagnostics and the results, see the author's article (Chibisova, 2018) showed that future teachers have a high level of communicative tolerance, are able to establish contact with a representative of a different culture, accept a different point of view, and adapt to a partner. With regard to ethnic identity, most respondents had positive ethnic identities, viewed their nationality positively, while recognizing the existence of others and not rejecting them.

Comparative analysis of questionnaires of students of linguistic and non-linguistic specialties showed that the study of foreign languages is not a key factor in the formation of intercultural competence, which suggests that it is necessary to develop all components of intercultural competence comprehensively - the cognitive one by transferring knowledge about other cultures, the functional one - to form intercultural communication skills, as well as the affective component - to form the right attitude to representatives of another culture. It is necessary to do this not only as part of the study of foreign languages, but also on the crosscurriculum level.

The questionnaire was also conducted for 23 British university students (the University of Oxford, the University of Edinburgh) using the same methods as with Russian students.

When analyzing the results on the tolerance questionnaire by V.V. Boyko, it can be stated that British students showed a significantly higher level of tolerance compared to Russian students. We see a very low score on scale 2 , that is, they do not rate themselves as a benchmark in assessing behavior and way of thinking. We observe significantly lower indicators according to scale 3 (categoricalness in the assessment of other people), scale 4 (inability to hide or smooth out unpleasant feelings when colliding with noncommunicable qualities of partners), scale 6 (the 
desire to fit a partner to yourself, make them "convenient"), scale 7 (inability to forgive others' mistakes, awkwardness, unintentionally caused you trouble), scale 8 (intolerance). In comparison with students of a Russian university, we see much greater tolerance, tolerance for other people, willingness to compromise and loyalty.

According to the questionnaire defining the types of ethnic identity (G.U. Soldatova, S.V. Ryzhova), British students showed almost complete absence of such a type of ethnic identity as ethno-nihilism, which indicates full recognition of their ethnic identity and the lack of need to deny it. According to the ethnic indifferency scale, we also see a significantly lower score compared to Russian students, which also confirms the acceptance of their identity by students. We also see low scores on scales 4,5,6 (ethno-egoism, ethno-isolationism and ethnofanaticism), which represent the stages of exaggeration of ethnic identity, meaning the emergence of discriminatory forms of interethnic relations. The scale of ethno-fanaticism has an indicator close to the results of Russian students and slightly higher than the indicators of the scales of ethno-egoism and ethnoisolationism. This is largely due to the fact that the University of Edinburgh is located in Scotland, which historically defends the right to national identity of Scots as opposed to the British. However, the average value of this scale for Scottish students is still not enough to argue that there is such a type of ethnic identity as ethno-fanaticism.

So, the analysis of questioning of British students showed existence of bigger tolerance, loyalty to manifestation of other behavior and thinking in comparison with Russian students that demonstrates consistency of the system of formation of intercultural competence with students of the British higher education institutions.

Therefore, we thought it appropriate to refer to the experience of teacher training in the UK. It has developed a certain system of training pedagogical personnel who are ready to work in a multicultural environment.

We have analysed the curriculum in fifteen UK universities (the University of Oxford, the University of Birmingham, the University of Manchester, etc.) in which there are teacher training faculties. The comparative analysis of the curricula revealed a number of features in the training of teachers, including the development of their readiness to work in a multicultural educational environment.

Analysis of these programs showed that in the universities of Great Britain the main focus is on the training of a teacher who is able to establish instruction in a class where there are completely different children on many grounds: ethnic, social, physical. A teacher capable of working with a wide variety of students is being trained. The concept of "multiculturalism" is not only an ethnic component. This definition is considered much more broadly in the UK, implying gender, racial, national, confessional diversity. In all pedagogical universities and colleges, the comprehensive discipline Diversity and Inclusion is taught, covering all possible differences between students, both at the social and physiological levels.

The teacher's indirect preparation for activities in the multicultural environment of educational schools is carried out by creating conditions for higher education for all students without exception. The organization of the educational environment takes into account the national, religious, physical and gender characteristics of students.

\section{Conclusions}

Studying the experience of Great Britain in the formation of intercultural competence among schoolchildren and future teachers allows us to determine the directions and trends of their development in modern Russian education at two levels: at the level of school education and at the level of higher education related to the preparation of teachers for work in multicultural classes.

In the field of schooling, in order to create conditions for the formation of intercultural competence of students, it is necessary to:

- $\quad$ increase the time of studying the disciplines of the multicultural specifics of the Russian and world community

- create a positive atmosphere of interaction between students of different cultural groups without infringing on the rights of a particular group

- establish educational programmes that take into account cultural, religious and other differences among students

- attract teachers from national, religious and other minorities to work in classrooms

- use interactive learning methods and technologies aimed at developing skills for 
successful intercultural communication in all conditions.

In the field of teacher training, the following steps should be taken to facilitate the readiness of the future teacher to work on the formation of intercultural competence of students:

- create equal opportunities for the education of representatives of all cultures, religions, nationalities and people with special developmental characteristics.

- use the help of mentors or tutors from senior students or students of the same cultural or national group.

- strengthen the practical component of the formation of intercultural competence. This is facilitated by actively developing student exchange programs, as a result of which students get the access to intercultural communication with representatives of completely different nationalities, faiths and cultures.

The formation of intercultural competence among future teachers will allow them to conduct systematic work confidently and consistently to form one among their students.

\section{Bibliographic references}

Apresyan, Y.D. (1997). New English-Russian dictionary: In 3 vols. Moscow: Russian language. Aziz, F., Saleem, T., Saleem, A., \& Batool, R. (2020). From pragmatic competence to intercultural competence: Pakistani ESL teachers perspectives of teaching interculturality in ESL classroom. Amazonia Investiga, 9(33), 37-45. https://doi.org/10.34069/AI/2020.33.09.4

Bakholskaya, N., Nazarova, O., Velikanova, S., Zharova, K., Igoshina, N., \& Chernykh, O. (2019). Inter-ethnic tolerance and its development among pedagogical students of higher educational institutions. Amazonia Investiga, 8(18), p.p 359-365. Retrieved from https://amazoniainvestiga.info/index.php/amazo nia/article/view/318

Barrett, M. (2012). Intercultural competence. EWC Statement Series, $2^{\text {nd }}$ issue, pp. 23-27.

Bednarz, F., \& Leoni, A. (2010). Reflective Strategies and Tools, Between Individual and Social Dimension. Diaries, Debriefing Sessions, Tutoring. Building Intercultural Competencies: A Handbook for Professionals in Education, Social Work and Health Care. Leuven: Acco, 210-236

Bennett, M. and Castiglioni, I. (2004) Embodied Ethnocentrism and the Feeling of Culture.
Handbook of Intercultural Training, 3rd Edition. Thousand Oaks: Sage, CA, 249-265.

Brustein, W. I. (2006). Paths to Global Competence: Preparing American College Students to Meet the World. IIE Networker, Spring, 23-25.

Byram, M. (1997). Teaching and assessing Intercultural Communicative Competence. Clevedon, UK: Multilingual Matters.

Chibisova, T.A. (2018). Formation of intercultural competence among students of pedagogical specialties. Psychology of education in the multicultural space. No. 2, 120-126.

Deardorff, D.K. (2006). The Identification and Assessment of Intercultural Competence as a Student Outcome of Internationalization at Institutions of Higher Education in the United States. Journal of Studies in International Education, Vol. 10 (3), 241-266

Galskova, N.D., \& Gez, N. I. (2007). The theory of teaching foreign languages. Linguodidactics and methodology. Moscow: "Centro" Publishing Center.

Grishina, A.V., Zelenov, A.A., \& Lunin, S.L. (2016). Diagnosis of the influence of ethnic identity on the formation of ethnic auto- and hetero-stereotypes in refugees and internally displaced persons from the regions of local military conflicts and the host population: educational manual. Moscow: CREDO.

Gudykunst, W.B. (1998) Applying anxiety/ uncertainty management (AUM) theory to Intercultural adjustment training. International Journal of Intercultural Relations, 22 (2), 227-250

Hall, E.T. (1968). The Silent Language. Fawcett, 62-65

UNESCO (2013). Intercultural Competences: Conceptual and Operational Framework. Retrieved from https://unesdoc.unesco.org/ark:/48223/pf000021 9768

Navaiyience, J., \& Rimkeviviene, V. (2013). Methodology for development of intercultural competence. European Commission. 36-41

Potorochina, G.E. (2001). Didactic conditions for the formation of intercultural competence of students of teacher training colleges. Izhevsk: UdSU, $250 \mathrm{p}$.

Sadokhin, A.P. (2009). Intercultural communication. Moscow: Infra-M, Alfa-M.

Safonova, V.V. (1996). The study of the languages of international communication in the context of dialogue of cultures. Voronezh: Istoki. Semenova, E.V. (2012). Interculture as the basis of the modern educational intercultural space: to pose the problem. Scientific journal Modern problems of science and education No. 5, 165. 
Sinicrope C., Norris J., \& Watanabe, Y. (2007). Understanding and assessing intercultural competence: a summary of theory, research, and practice (technical report for the foreign language program evaluation project). Second Language Studies, Vol. 26(1), 1-58.
Spitzberg, B.H. (2000) A Model of Intercultural Communication Competence. Intercultural Communication: A Reader, 9, 375-387.

Zeleeva, V.P. (2015). To the problem of defining the concept of "intercultural communication" in pedagogical science. Kazan Social and Humanitarian Bulletin, (14), 43-48. 